"This is the peer reviewed version of the following article: 'A.M. Gurnell et al., 2018. Trees and wood: working with natural river processes. Water and Environment Journal, early view, which has been accepted for publication in final form at DOI: 10.1111/wej.12426. This article may be used for non-commercial purposes in accordance with Wiley Terms and Conditions for Self-Archiving."

\title{
TREES AND WOOD: WORKING WITH NATURAL RIVER PROCESSES
}

Angela Gurnell ${ }^{1}$, Judy England², Lydia Burgess-Gamble ${ }^{2}$

${ }^{1}$ School of Geography, Queen Mary University of London

${ }^{2}$ Environment Agency

\section{ABSTRACT}

A history of land clearance and riparian tree and wood management has resulted in limited riparian woodland and wood along British rivers. However, river management approaches are now being promoted that 'work with natural processes' to reduce flood risk through measures intended to restore, protect and emulate the natural function of catchments, rivers, estuaries and coasts. Wood has started to be reintroduced into river channels during river restoration and natural flood management activities, but this needs to be undertaken using appropriate quantities, locations and designs that mimic natural tree-wood features. This paper reviews the knowledge that is needed to support wood reintroduction activities including (i) the characteristics of the riparian tree species and wood that are present; (ii) the importance of river size relative to that of trees and wood pieces; and (iii) the way trees, wood and geomorphic processes interact across rivers and floodplains of different energy and style.

\section{KEY WORDS}

Riparian woodland, large wood, river size, river type, channel morphology, floodplain morphology

\section{INTRODUCTION}

Catchment-wide human activities associated with agriculture, housing development, industry and transport modify the quality and pathways of water and sediment draining to river networks as well as placing severe constraints on the functioning of rivers and floodplains (Sear et al., 2000). At the same time, river channel, flow, and sediment management activities, relating for example to the development of water resources, navigation channels and flood defences, have also severely modified the natural form and mobility of river channels and their floodplains (e.g. Nilsson and Svedmark, 2002; Downs et al., 2013).

However, over the last two decades there has been an increasing emphasis on developing river management approaches that 'work with natural processes' to reduce flood risk by implementing measures which aim to 'restore, protect and emulate the natural function of catchments, rivers, estuaries and coasts' (Pitt, 2008). Also referred to as 'natural flood management' these types of measures help to both restore and sustain river ecosystem services that benefit humans while also maintaining river ecosystem health (Palmer et al., 2005, 2014; Environment Agency., 2017). Over the same time period, the river science literature has increasingly emphasised the role of vegetation as well as water and sediment in controlling river morphodynamics (Corenblit et al., 2007, 2009; Environment Agency, 2014; Gurnell, 2014; Gurnell et al., 2016), benefitting wildlife (Pilotto et al. 2014; Thompson et al. 2017), and adapting to climate change (Perry et al. 2015), particularly by 
shading the water surface and so helping to ameliorate changes in water temperature. In particular, the influence of riparian trees and large wood (wood pieces greater than $1 \mathrm{~m}$ in length and $0.1 \mathrm{~m}$ in diameter) on river systems has been emphasised (e.g. Abbe et al., 2003; Gregory et al., 2003; Collins et al., 2012, Ravazzolo et al., 2015, Wohl, 2015)

A

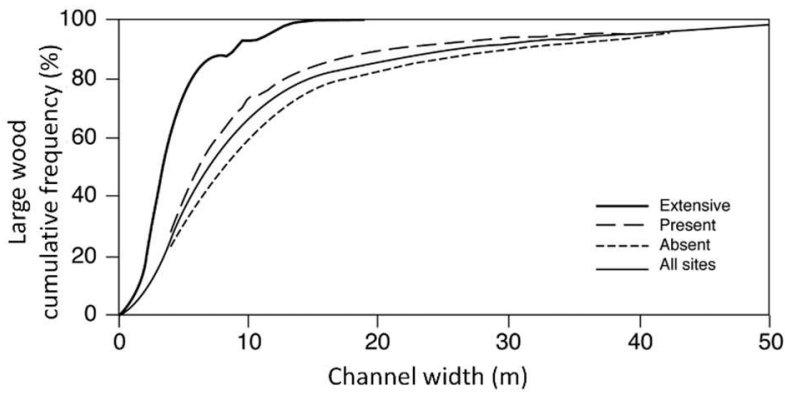

B
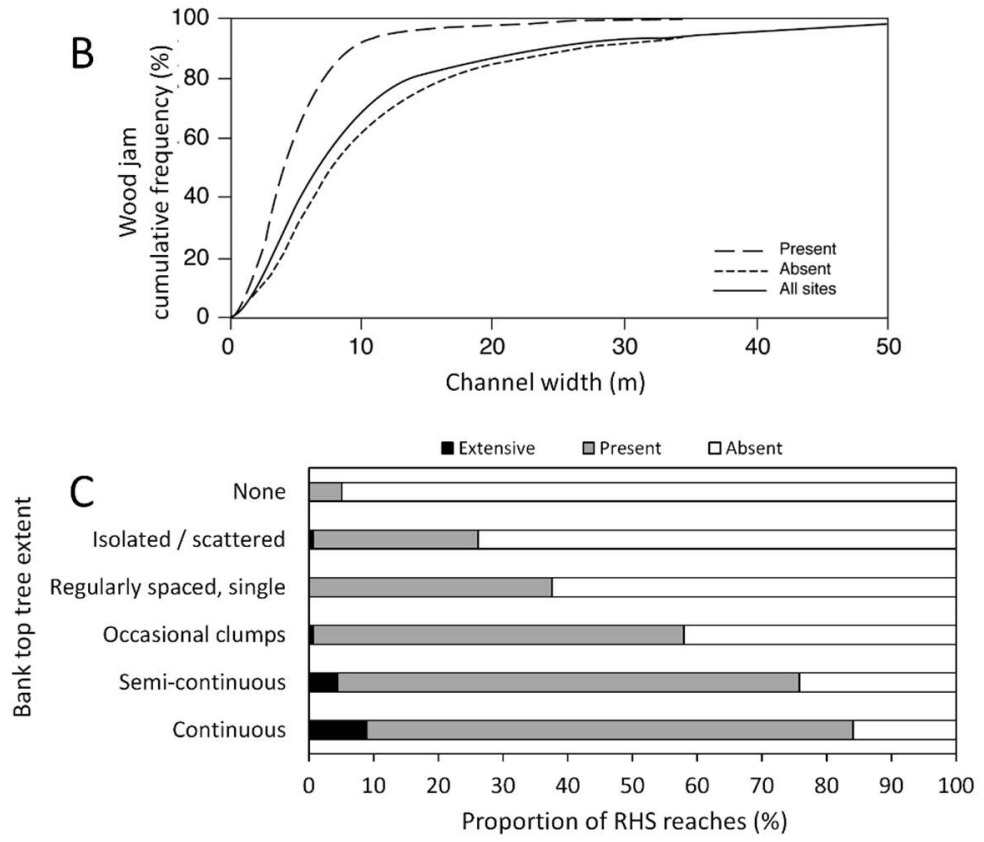

Figure 1: Some characteristics of wood in British rivers extracted from River Habitat Surveys (after Linstead and Gurnell, 1999). A. Percentage cumulative frequency of RHS reaches with large wood extensive, present or absent according to their channel width. B. Percentage cumulative frequency of RHS reaches showing wood jams present or absent according to their channel width. $C$. Proportion of RHS reaches with large wood extensive, present or absent according to the extent of trees on the bank tops.

As a result of a long history of land clearance coupled with intensive riparian tree and large wood management, the presence of riparian woodland and large wood along British rivers is limited (Gurnell and Petts, 2002). Analysis of approximately 4500 River Habitat Surveys collected in the late 20th century (Linstead and Gurnell, 1999) illustrates the generally low presence of large wood in British rivers, with extensive wood coverage being particularly rare and confined to small streams (< 10 m channel width, Figure $1 \mathrm{~A}$ ) with no surveyed river reaches showing extensive wood jams (Figure 1B). The critical link between riparian trees and wood is also revealed. The presence of an extensive cover of large wood within the river channel is almost entirely confined to reaches with a continuous tree cover along both banks (Figure $1 \mathrm{C}$ ). The severity of wood removal and riparian tree maintenance along British rivers has decreased in the last 20 years. Although riparian woodland and large wood within the channel and its margins remain quite rare phenomena along British rivers, 
wood has started to be reintroduced into river channels during restoration and natural flood management activities (e.g. Mott, 2010; RRC, 2013). It is crucial that such measures are applied in appropriate quantities, locations and with designs that mimic natural tree-wood features if they are to have the highest likelihood of functioning in a near-natural manner in terms of their impact on flow hydraulics, flood attenuation, and landform / habitat building. To achieve this, a more detailed understanding of natural tree-wood-fluvial process interactions in a British river context is required, reflecting:

(i) Characteristics of the riparian tree species and the type(s) of wood that are present.

(ii) The size of the river relative to the size of the trees and wood pieces.

(iii) The energy and style of the river system

This paper develops these three themes using illustrative examples from some lightly-managed reaches of British rivers. In this way, we indicate the potential outcomes of incorporating riparian trees and large wood into British river management in ways that are sensitive to the river size, energy and type. We do not provide precise prescriptions but we indicate important issues that require further research to fully inform the management of riparian trees and large wood along British rivers.

\section{WOOD PROPERTIES AND THE WOOD CYCLE}

Since wood is recruited into rivers from trees, there is little logic in considering wood management in isolation. Therefore, whenever possible, the use of wood to induce physical habitat complexity and turnover or to attenuate flows in rivers should be coupled with some restoration of riparian woodland to ensure a sustainable future supply of wood. Linking trees to wood to river form and dynamics implicitly acknowledges that these are linked in a river 'wood cycle'.

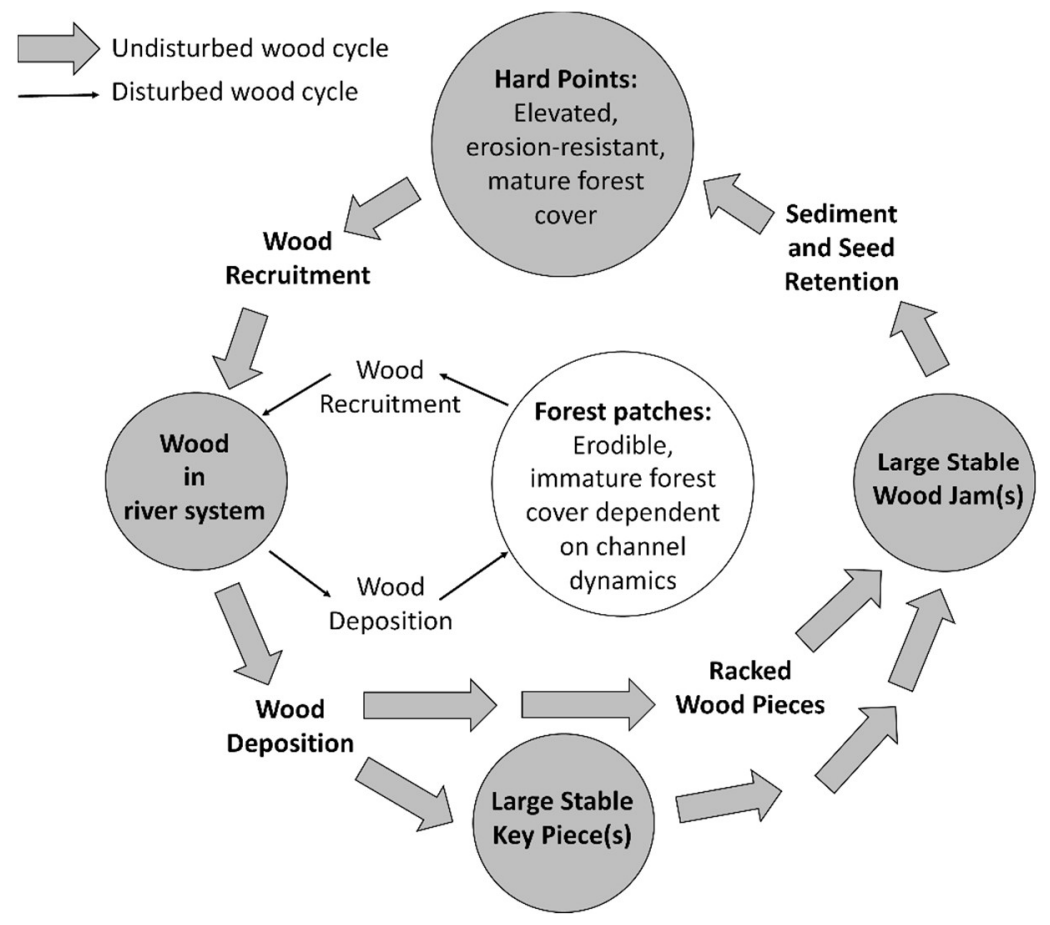

Figure 2: The floodplain large-wood cycle (simplified after Collins et al., 2012) 
The 'floodplain large-wood cycle' concept was formally proposed by Collins et al. (2012) for application to river valleys in the Pacific coastal temperate rainforest of the north-west USA (Figure 2). Collins et al. considered the functioning of a pristine river system with a complex wandering river pattern and well-developed floodplain covered by mature forest (main tree species: Sitka spruce (Picea sitchensis), western hemlock (Tsuga heterophylla), Douglas-fir (Pseudotsuga menziesii), western redcedar (Thuja plicata), red alder (Alnus rubra), black cottonwood (Populus balsamifera trichocarpa)). In this context, the mature forest is comprised of very large trees which deliver large, mainly dead wood pieces to the river, which have low mobility and act to anchor the wood jams that accumulate around them. These very large wood pieces decay slowly and accumulate as large, stable wood jams within the river channel and its margins. Over time, the jams trap further dead wood, sediment and seeds, and slowly become incorporated into the floodplain as difficult-to-erode, woodreinforced 'hard points' that support seedling germination and growth over long periods into very large trees (Figure 1, undisturbed wood cycle). Wood removal from the river or harvesting of the largest trees disrupts the floodplain wood cycle by preventing the input of the very large mature trees and wood pieces that become the core of floodplain hard points and persist long enough for mature forest growth and subsequent very large wood delivery (Figure 1, disturbed wood cycle). Therefore, although branches and smaller trees may still enter the river, the removal of the very largest, mature trees from the wood cycle leads to shortening of the cycle, incorporation of generally smaller wood pieces, the development of a more erodible floodplain, and thus less time for trees to grow to maturity and deliver very large wood pieces to the river. The result is transformation of the river and its floodplain pattern from a complex, stable wandering pattern with a floodplain forest of varied form and age structure into a less complex, less stable, braided pattern with a younger and less complex floodplain forest.

Even in unmanaged conditions, the wood cycle on British rivers is very different from the above example. Coniferous trees are rare in established natural British woodland. Instead, it is dominated by deciduous hardwood species that do not reach such a large size as the species in the above example. Furthermore, intensive tree management and harvesting has resulted in river margins being dominated by pioneer riparian species drawn from the Salicaceae (willows, poplars) and Betulaceae (alders). These species produce wood that is smaller, less dense and decays more quickly than the species cited in the above example. These properties make the wood more mobile within rivers and thus likely to drive a faster wood cycle. However, these species also produce wood that is more irregular in shape and thus more susceptible to snagging. In addition, particularly for the riparian Salicaceae, the wood is not universally dead but can regenerate ('living wood').Both irregularity of form and the potential for regeneration reduce wood mobility within the river system. In particular, the mobility of living large wood is drastically reduced once it is anchored by adventitious root systems. Furthermore, it rapidly instigates the development of new trees, providing a living structure that traps other mobile wood pieces as well as sediment, producing river and floodplain features that have the potential to function in a similar manner to the dead wood hard points of the US example (e.g. Gurnell et al., 2001, 2005).

Thus, British rivers are subject to a wood cycle that incorporates different tree species from the US example and a mix of dead and living large wood. At present, scientific knowledge of the functioning of such a cycle is limited. There is an urgent need to fully understand how unmanaged wood and trees of different species might interact with fluvial processes in a British context. In particular, we need to understand the characteristic river and floodplain morphological features that might result and their stability and turnover, taking into account typical in-channel and riparian wood quantities, piece sizes, densities, decay rates, and abilities to regenerate. 


\section{RIVER SIZE}

A critical dimension in interactions among riparian trees, wood and river channels is the size of the channel relative to the size of the wood and trees (Figure 3). In 'small' channels where the riparian trees are much taller, when scaled to river width, and thus much of the wood is longer than the river width, wood tends to remain where it falls, showing an irregular spatial pattern. As the river width increases to an 'intermediate' size, a decreasing proportion of the wood is sufficiently large to span the channel. In this case, a few large wood pieces are sufficiently stable to act as key pieces around which more mobile pieces accumulate to form wood jams, many of which span the entire channel width to form wood dams. With further increases in channel width, none of the wood pieces are sufficiently large to span the channel. In these 'large' rivers, wood tends to be quite mobile and is mainly swept into the channel edges or around in-channel obstructions such as bars or islands, where it snags on morphological irregularities, vegetation and other snagged wood to build wood accumulations (Figure 3A).
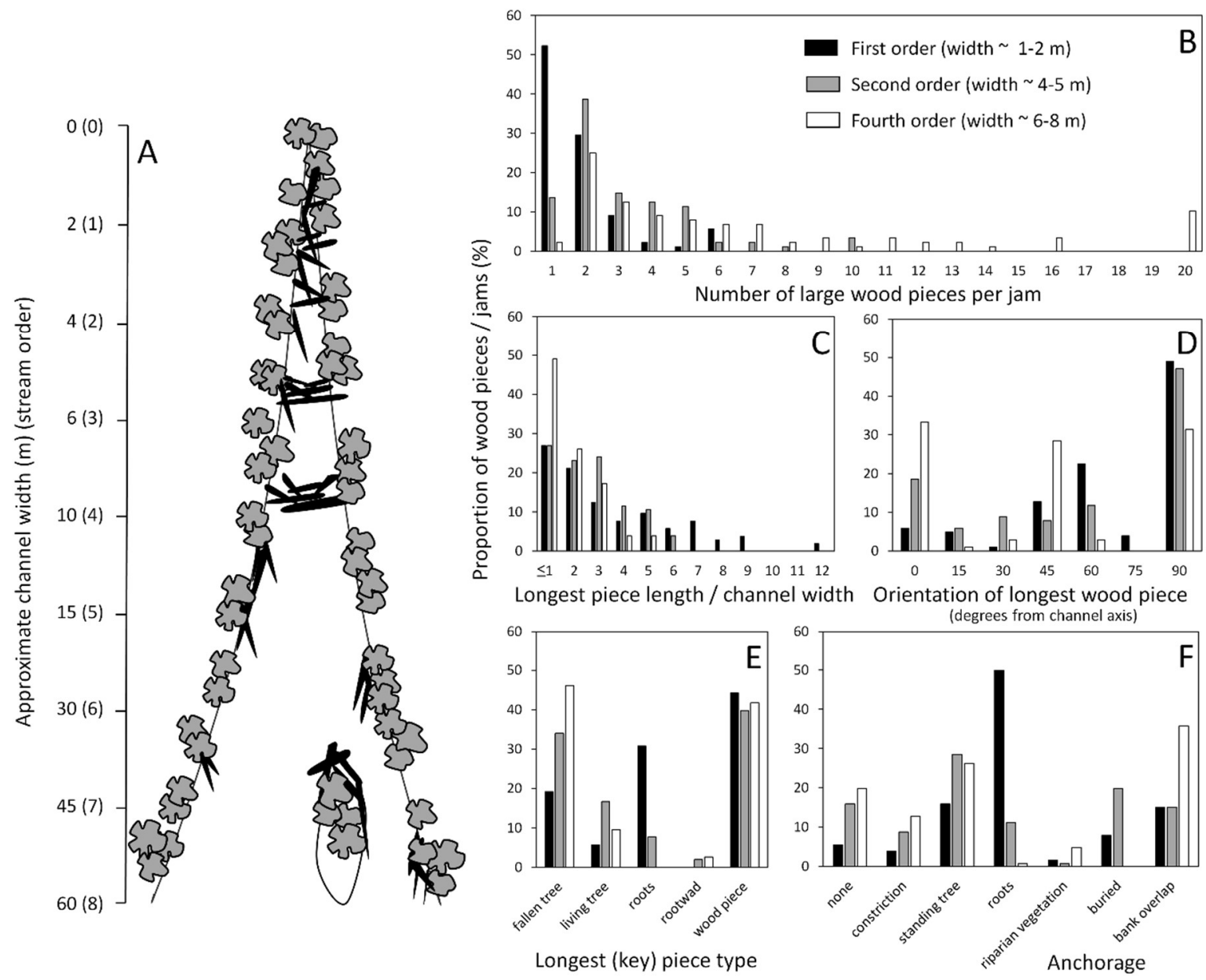

Figure 3: Large wood and river size. A. Schematic changing spatial distribution of in-channel large wood with increasing river size (note that the values for channel width and order are only indicative, after Sedell et al., 1988). The proportions (\%) of wood jams and their key pieces in First, Second and Fourth Order reaches of the Highland Water, New Forest, England displaying different (A) numbers of large wood pieces ( $>1 \mathrm{~m}$ long, $>0.1 \mathrm{~m}$ wide), (B) ratios of longest wood piece length to channel width, (C) orientation of longest wood piece, ( E) types of key piece, and (F) anchorage mechanisms. 
Observations from the Highland Water, New Forest, Hampshire illustrate the concepts of Figure $3 \mathrm{~A}$ in a British, low gradient, lightly-managed, deciduous woodland setting (for a full description see Gurnell et al., 2002). The measurements were taken from over 300 accumulations of wood along the river. They show an increase in the number of large wood pieces (Figure 3B), a decrease in the ratio of longest (key) wood piece length to channel width (Figure $3 \mathrm{C}$ ) and a change in the orientation of the longest wood pieces from cross-channel (90 degrees) to increasingly parallel to the channel centre line ( 0 degrees) as the channel width increases. The data show that although large wood pieces form the key pieces in accumulations in all channels, tree roots form important anchors for wood accumulations in the smallest streams, whereas channel constrictions, standing trees and bank overlap / burial gain in importance as the river channel widens.

Further analysis of channel-spanning wood dams on the Highland Water (Gurnell and Sweet, 1998, Gurnell et al., 2002) suggests an average of 4 dams per $100 \mathrm{~m}$ channel length. Sizeable wood dams are concentrated in the 4 to $5 \mathrm{~m}$ width ( 5 per $100 \mathrm{~m}$ ) and 6 to $8 \mathrm{~m}$ width channels ( 2 per $100 \mathrm{~m}$ ) because low wood mobility prevents the development of major dams in the smallest ( 1 to $2 \mathrm{~m}$ width) stream channels. The mature woodland along the Highland Water prevents significant lateral channel migration. Channel positional changes depend on avulsions, usually induced by wood dams, and down-cutting of new channels into the floodplain where this is not prevented by dense root networks. Furthermore, in addition to free-formed pools and riffles, most of the geomorphic features observed in this gravel bed river can be attributed to tree-wood-channel interactions, including the position of bends (often centred on mature trees), forced pools, bars, islands, and heavily undercut banks (Gurnell and Sweet, 1998).

The data presented in Figure 3 and the comments on geomorphic features and channel dynamics only refer to one British low-gradient headwater river (maximum surveyed width $-8 \mathrm{~m}$ ). This is a useful case study that is likely to be representative of many British lightly-managed, wooded, headwater rivers, although log steps (wood structures, usually also incorporating some boulders, that form a distinct step in the river long profile) are likely to be an increasingly important geomorphic feature in steeper systems. Certainly features similar to those observed in the New Forest are apparent in the small number of other lightly managed, wooded, British river reaches that have been observed by the authors. Nevertheless, observations are needed from a sizeable sample of naturally-functioning British headwater rivers of different gradient / energy and riparian woodland type. These data are needed if we are to understand the quantities and piece sizes of wood and the scale-dependent way in which they form different styles of wood accumulation in a British context. Such knowledge is crucial to inform (i) where we could stop or reduce maintenance to allow recovery of natural processes, and (ii) where and how we can design and position artificial wood structures to emulate natural forms and processes in order to help to restore floodplain connectivity in British rivers. Furthermore, river size is only one influence. The geomorphic style of river is also important and becomes increasingly so when larger rivers with well-developed floodplains are considered.

\section{RIVER ENERGY AND TYPE}

The simple downstream changes summarised above for the Highland Water, refer to single-thread headwater streams, which are 'small' to 'intermediate' in size when scaled for the large wood that is present. The channel form and geomorphic features mentioned are observed in many 'small' to 'intermediate' wooded streams, whether they are confined by their valleys or have a floodplain (for a review see Gurnell, 2013). From the perspective of restoration and management, it is important to understand that riparian trees and wood accumulations strongly affect channel morphology, geomorphic features and their stability, which in turn impact on wood stability. These feedbacks are 
supported by observations on three reaches of the Highland Water that have been subject to differing channel and wood management histories (Figure 4).

The Highland Water has extensive lengths of essentially unmanaged river channel bordered by unmanaged riparian woodland, mainly composed of deciduous hardwood species with some conifers (e.g. Figure 4A). However, some reaches have been channelized (straightened and frequently deepened). In some of the early channelized reaches (e.g. Figure 4B), the woodland bordering the channel is mature and is very similar to that bordering the unchannelized reaches, but reaches that were channelized later were associated with conifer planting (e.g. Figure 4C) such that virtually no deciduous hardwoods were present along the river margins at the times of survey. In 1987 and 1989, severe wind storms caused widespread tree fall and the release of large quantities of wood to the river system. In 1989, reaches A and B (Figure 4) were cleared of large wood but reach C was not cleared. This partly natural experiment demonstrates the crucial importance of tree-woodchannel interactions for the retention / mobility of large wood and thus for the physical complexity of naturally-functioning 'small' to 'intermediate' sized woodland river channels. Reach A has a complex planform guided by riparian trees and extensive roots interacting with flow and sediment processes. For clarity, geomorphic features are not shown in Figure 4 but are mentioned in the reach descriptions that follow. Despite wood clearance in 1989, wood accumulations were virtually reinstated to their 1982 pattern and type by 1996, indicating the importance of tree-channel forms for trapping and retaining wood as semi-permanent structures of high hydraulic and geomorphic importance. However, many pools were infilled following wood clearance and had not fully recovered by 1996 . Reach $B$ has a very simple planform, although root systems add roughness to the channel margins. This reach had retained wood by 1982, following up to 60 years of wood accumulation. However, the low wood retention ability of this morphologically-simple channel is illustrated by the weak recovery of wood accumulations by 1996. Furthermore, in 1982 the reach had numerous pools and gravel bars around the in-channel wood accumulations, but these had either disappeared or were drastically reduced in size by 1996. Reach C also has a simple planform and in 1982 there was poor root exposure along the banks. The lack of wood in the channel in 1982, following around 20 years during which wood could have accumulated, indicates the young age of the planted trees and the poor wood retention capability of this reach for the likely small pieces of wood that may have been delivered to the channel. However, by 1997, wood had started to accumulate in significant bank-side accumulations, where it had been retained by fallen conifer trees, blown down in the intervening wind storms. This illustrates the way in which fallen trees can provide retention structures for wood in 'intermediate' channels. Furthermore, if not managed, these wood structures are likely to persist for long enough to initiate increased channel sinuosity and a range of geomorphic features. Indeed, whereas the 1982 channel in reach C showed several small pools and side bars, by 1997 there were new and greatly enlarged side bars, some supporting vegetation growth, so that the channel thalweg (line of maximum depth) had an increased sinuosity in 1996 in comparison with 1982. In addition, although the number of pools was similar to 1982, the pools present in 1997 were larger.

Based on the observations from the Highland Water, and supported by knowledge of other British streams, naturally-functioning 'small' to 'intermediate' woodland channels appear to be morphologically complex, supporting numerous tree-, wood- and sediment-related geomorphic features and thus a complex physical habitat mosaic. The dynamics of large wood in these systems is inversely proportional to the size of the wood, with pieces longer than 2.5 times the channel width being near-immobile (e.g. Dixon and Sear, 2014). Wood in these systems tends to accumulate in particularly retentive locations (e.g. in channel constrictions, snagged within exposed roots, braced against standing trees, particularly where they overhang or are located on bars/islands within the 
channel), in turn forming retention structures for mobile wood pieces and reducing in-channel wood mobility to low levels and short distances, although there may be considerable turnover of smaller large wood pieces within individual wood accumulations as wood moves downstream but accumulations stay in place ( (e.g. Dixon and Sear, 2014). Furthermore, over-bank wood, floated into / along river margins during overbank flow events, is soon intercepted by standing trees or side channels. In contrast, channelized rivers provide poor wood retention and high wood mobility. However, when stable, large wood pieces enter these channels, they act as wood retention structures and initiate channel adjustments. Such adjustments, when supported by riparian woodland, have the potential to self-restore these channels to a more natural wood-retentive, morphological state. This in turn has the potential to provide other ecosystem service benefits such as reductions in flood risk, improvements to biodiversity and water quality etc.
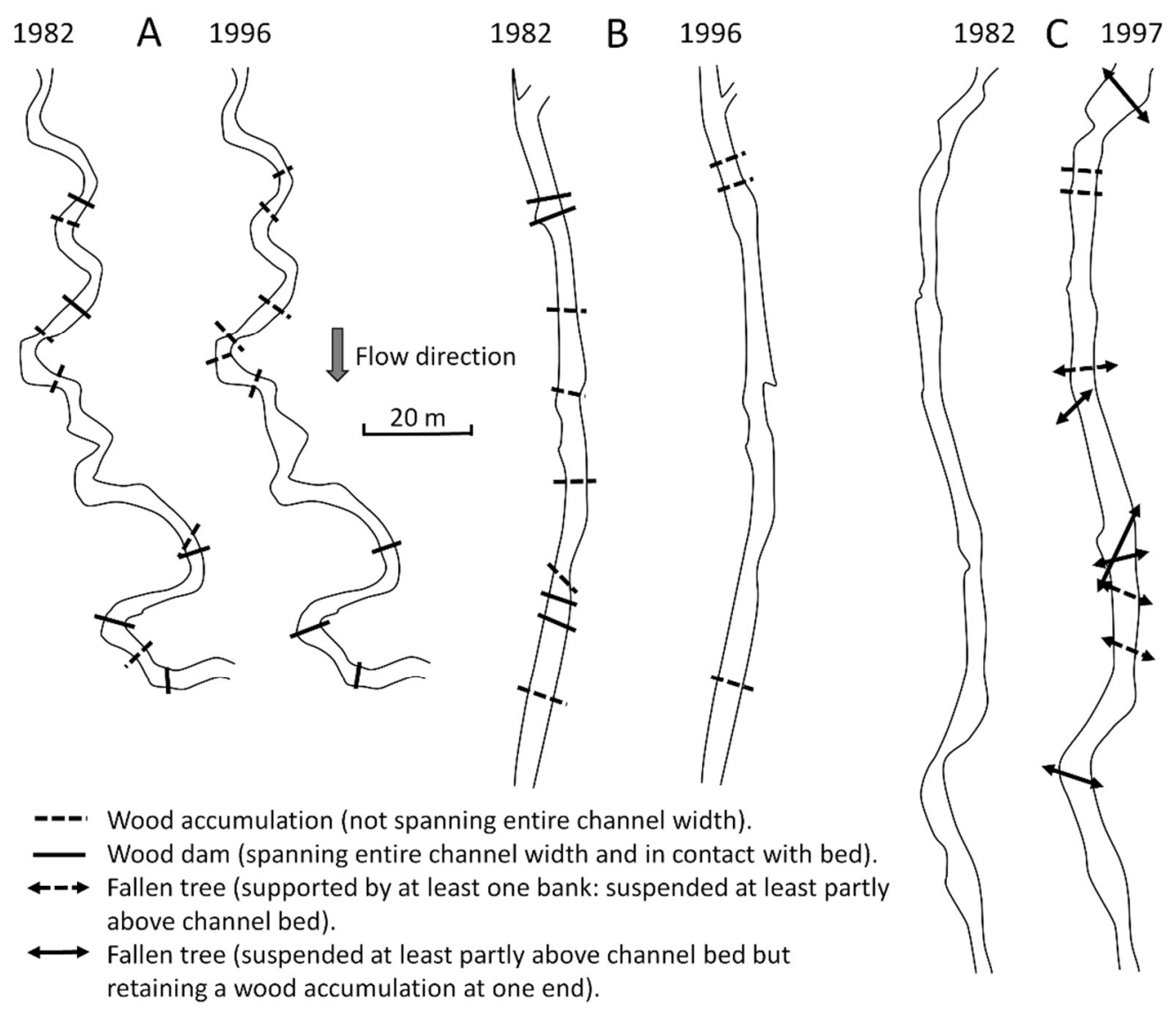

Figure 4: Distributions of wood accumulations, wood dams and fallen trees on three reaches of the Highland Water in 1982 and 1996/7 (simplified and redrawn from Gurnell and Sweet, 1998).

A. Natural channel planform, mature, mixed, unmanaged riparian woodland, wood cleared in 1989

B. Channelised, probably in 1920s, mature, mixed, unmanaged riparian woodland, wood cleared in 1989

C. Channelised in 1960 s, plantation conifers, no wood clearance

Where wood is present in 'large' channels, its retention and contribution to channel and floodplain morphodynamics depends upon the river type. Many river types exist with differences in their bed material calibre, sinuosity, number of channel threads, and stability (e.g. England and Gurnell, 2017). Currently, the main types of 'large' river found in Britain are single thread straight/sinuous and meandering rivers with cobble, gravel or sand beds. These are found in river valleys of intermediate 
to low gradient with the bed material generally becoming finer as the gradient decreases.

Wandering rivers, which support one or more channels and islands and typically a cobble-gravel bed, occur in some steeper (higher energy) situations. It is also likely that low energy anabranching rivers, which have numerous channels separated by stable well-vegetated islands and typically have sandsilt beds, were probably quite common in very low gradient settings prior to human land clearance and channel interventions. All of these river types have distinctive channel and floodplain features, which are both enhanced and modified when bordered by naturally-functioning riparian woodland (for an international review, see Gurnell et al., 2013). Unfortunately there are few examples of British river reaches that exhibit these natural functions, but Figure 5 gives some examples of partlyfunctioning reaches known to the authors.

Sinuous and meandering channels typically show sedimentary point bars on the inner bank of bends. In some cases scrolls form parallel ridges on point bars and become incorporated into the inner bank floodplain as the channel migrates. Such features can be explained by sediment erosion, deposition and supply processes as water flows around the river bend (e.g. van de Lageweg et al., 2014). However, along wooded rivers, large wood is often incorporated into the scrolls (Nanson, 1980, 1981), helping to reinforce and accentuate them, and where living wood is present, tree growth traps further sediment and wood to rapidly produce root-reinforced ridges (Zen et al., 2017). The contribution of living large wood incorporated into developing point bars (Figure $5 \mathrm{~A}, \mathrm{~B}$ and C) along an artificially created section of the River Cole, can be clearly seen in the lines of shrubs emerging on the bars in 2007 (Figure 5B, dashed white lines) and producing well developed woodland by 2013. The Cole reach is confined by embankments, but where rivers interact freely with wood and trees, a strongly ridged floodplain develops (Figure 5G), providing storage for floodwaters and supporting a complex of wet to dry habitats on and between the ridges.

Some lower energy sinuous and meandering rivers develop counterpoint bars on the outside of their bends. Bars developing in this situation are typically composed of fine sediment, which, unless strongly cohesive, is easily re-mobilised. However, wood deposition can help to stabilise these fine deposits, which are further reinforced if the wood sprouts or supports seed germination to produce a woodland cover. On the lower River Dee, close to the English-Welsh border, counterpoint bars have developed since 1948 (e.g. Figure 5 D, E) accompanying riparian tree recovery and flow regulation. The bars enlarge as the river migrates (see the change from the 1948 channel position, marked as white lines and overlain on the 1979 channel, Figure 5E) and their riparian tree cover rapidly traps fine sediment and mobile wood when inundated during high flow events, aggrading the bar surface so that it can eventually become incorporated into the floodplain. At another counterpoint location (Figure 5F), a ridged area of floodplain is exposed. It is unclear whether the ridges were initiated by counterpoint scrolls or channel cut-offs, but it is interesting to see large wood pieces accumulating between the ridges at the downstream margin of the ridged area (area enclosed by white dashed line in Figure 5F).

Most low-gradient British floodplains have been drained and converted to agriculture, so no lowenergy anabranching rivers remain. However, where rivers maintain several channels that have some natural function (e.g. the River Frome, Dorset), it is possible that they supported wooded anabranching systems in the past. An example of anabranching through wet woodland on a short section of the River Wey floodplain, Surrey (Figure $5 \mathrm{H}$ and I) illustrates the complexity of these remarkably stable systems

\section{CONCLUSIONS}


There is no doubt that riparian trees, wood and river channels interact to build morphologically complex channels and floodplains that have the potential to deliver numerous ecosystem services and, because of their varied physical habitat mosaic, which is associated with an overall increase in flow resistance, are capable of attenuating floods, supporting a diverse range of organisms and life stages and adaptation to climate change. The challenge is to find ways of incorporating these beneficial processes, functions and forms into a landscape that is heavily used by humans. Much practical research has been devoted to natural flood management and restoration of British rivers that attempts to work with natural processes. However, there is a need to establish more sustainable ways of incorporating trees and wood that takes account of some of the points raised in this paper. In particular:
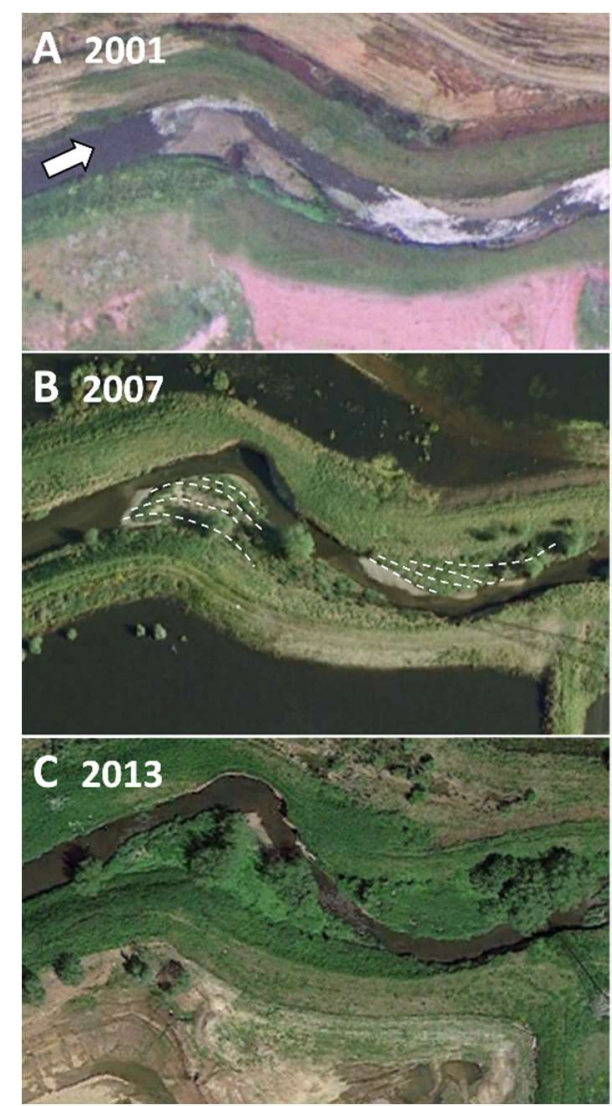
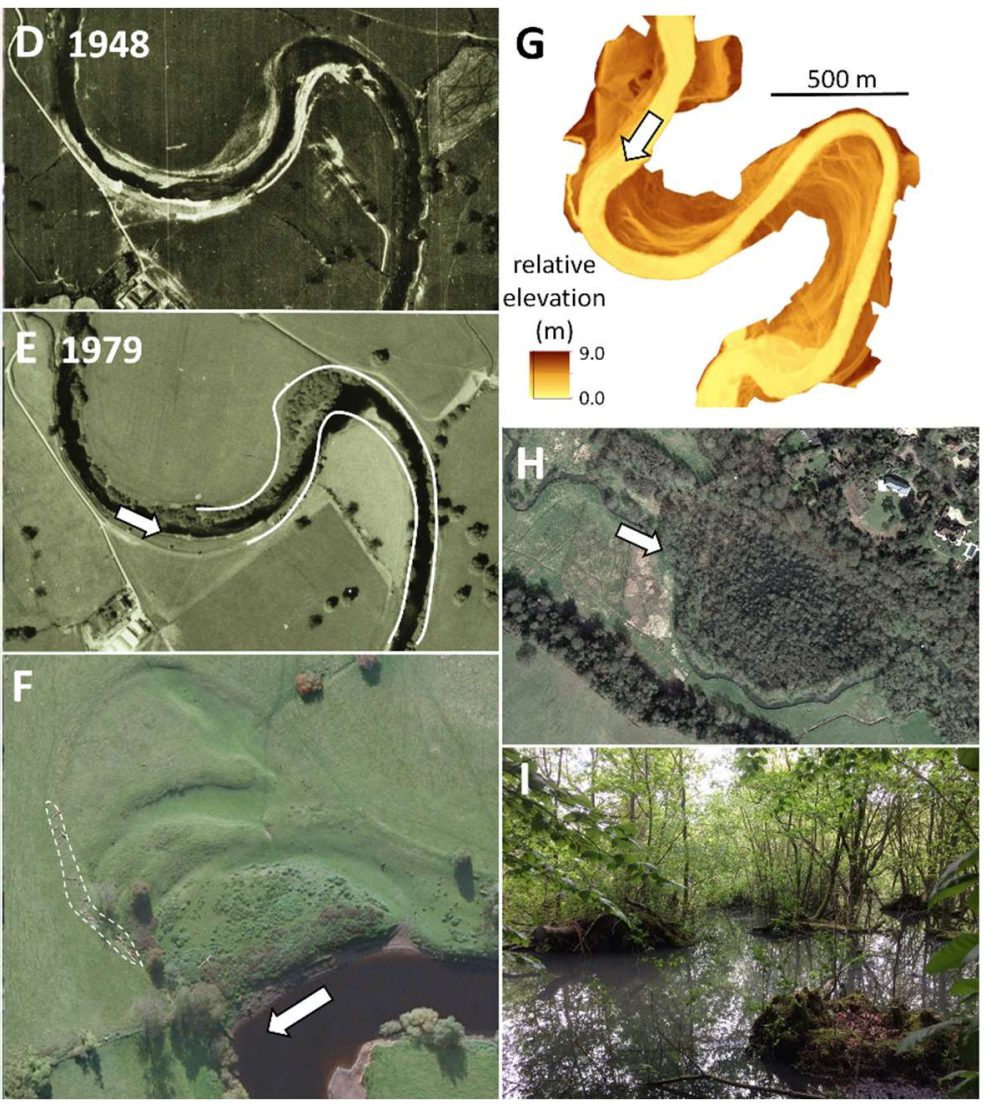

Figure 5: The River Cole near Birmingham showing scrolled point bar development (on the inner bank) along a newly created channel section (A, B, C). The lower River Dee near the English-Welsh border showing counterpoint bar development (on the outer bank) as riparian vegetation colonises following World War 2 (D, E) and a section of ridge and furrow floodplain (F). A Digital Elevation Model of a ridge-and-furrow floodplain created by scrolled point bar development on a laterally migrating Italian river (G). Anabranching channels developing across a wet, wooded section of the River Wey floodplain, Surrey $(\mathrm{H}, \mathrm{I})$. (Images A, B, C, F and G were obtained from Google Earth: A. Image (C) 2018 The Geolnformation Group, B. Image (C) 2018 Infoterra Ltd \& Bluesky, C. Image @ Landsat / Copernicus, F. Image @ 2018 Bluesky, H. Image @ Landsat / Copernicus, image $D$ was obtained from the Aerial Reconnaissance Archives when they were held at the University of Keele)

1. Trees and large wood interact with river channels in different ways according to the size and type of river and the type of trees that are present. 
2. We need a better understanding of the typical quantities of large wood found in naturally functioning British rivers and the degree to which this wood is dead or can regenerate.

3. We need an understanding of where wood is likely to accumulate, the typical structure (size, orientation, number and size of keys pieces) of wood accumulations, the types of geomorphic feature they help to build in rivers of different sizes and the stability / mobility of these features and their included wood.

4. In 'small' to 'intermediate' sized rivers, we need to recognise the over-riding impact of riparian trees on the locations, types and stability of wood feature, and the joint impact of wood and trees on river margin and floodplain morphological development. In 'large' rivers, we need to understand how wood and trees accelerate and enlarge river and floodplain feature development so that topographic complexity is enhanced.

5. To produce all of the above knowledge, a systematic analysis of the characteristics of naturally-functioning reaches of British rivers is needed, to expand the examples and observations presented here. Such analysis needs to focus on both river size and type, developing a more informed typology of naturally-functioning British rivers than we have mentioned. The required knowledge can emerge from analysis of present naturallyfunctioning river characteristics, of natural forms developing in human-modified rivers, and of hints of the past character of rivers gained from analysis of historical and contemporary air photographs, maps and airborne Lidar data.

6. The availability of such knowledge should allow: (i) wood-retentive river channel and floodplain reaches that can reduce wood mobility to be recognised; (ii) locations where wood accumulations are likely to be stable to be identified; and (iii) reaches to be recognised where a reduction of river maintenance would allow trees to help restore river floodplainconnectivity. In addition, (iv) where artificial wood structures are to be introduced, appropriate locations and designs can be developed that are sympathetic to the size and type of river and the location under consideration. 


\section{ACKNOWLEDGEMENTS}

Figure 5 includes five images from Google Earth, and from the following suppliers: The Geolnformation Group, Infoterra Ltd, Bluesky, Landsat / Copernicus (see Figure caption for precise attributions). In using these images, we have conformed to guidelines available from http://www.google.com/permissions/geoguidelines/attr-guide.html (accessed 16 December 2017) including image attributions in the Figure caption that conform to the text of your attribution must say the name "Google" and the relevant data provider(s), such as "Map data: Google, DigitalGlobe"' and we have not obtained written permission to use these images because the guidelines state that 'Due to limited resources and high demand, we're unable to sign any letter or contract specifying that your project or use has our explicit permission'.

\section{REFERENCES}

Abbe, T.B., Brooks, A.P. and Montgomery, D.R., 2003. Wood in River Rehabilitation and Management. In: S.V. Gregory, K.L. Boyer and A.M. Gurnell (Editors), The ecology and management of wood in world rivers. American Fisheries Society Symposium 37, Bethesda, Maryland.

Collins, B.D., Montgomery, D.R., Fetherston, K.L., Abbe, T.B. (2012) The floodplain large-wood cycle hypothesis: A mechanism for the physical and biotic structuring of temperate forested alluvial valleys in the North Pacific coastal ecoregion. Geomorphology, 139-140, 460-470.

Corenblit, D., Steiger, J., Gurnell, A.M., Tabacchi, E. and Roques, L., 2009. Control of sediment dynamics by vegetation as a key function driving biogeomorphic succession within fluvial corridors. Earth Surface Processes and Landforms, 34(13): 1790-1810.

Corenblit, D., Tabacchi, E., Steiger, J. and Gurnell, A.M., 2007. Reciprocal interactions and adjustments between fluvial landforms and vegetation dynamics in river corridors: A review of complementary approaches. Earth-Science Reviews, 84: 56-86.

Curran, J.H. and Wohl, E.E., 2003. Large woody debris and flow resistance in step-pool channels, Cascade Range, Washington. Geomorphology, 51: 141-157.

Dixon, S.J. and Sear, D.A., 2014. The influence of geomorphology on large wood dynamics in a low gradient headwater stream, Water Resources Research, 50, 9194-9210.

Downs PW, Dusterhoff SR, Sears WA. 2013. Reach-scale channel sensitivity to multiple human activities and natural events: Lower Santa Clara River, California, USA. Geomorphology 189: 121134.

England, J., and Gurnell, A.M. (2016) Incorporating catchment to reach scale processes into hydromorphology assessment in the UK. Water and Environment Journal, 30, 22-30.

Environment Agency. 2017. Working with Natural Processes - Evidence Directory. Project SC150005. Environment Agency, Bristol, UK.

Environment Agency, 2014. Aquatic and riparian plant management: controls for vegetation in watercourses. Project SC120008. Environment Agency, Bristol, UK.

Gomi, T., Sidle, R.C., Woodsmith, R.D. and Bryant, M.D., 2003. Characteristics of channel steps and reach morphology in headwater streams, southeast Alaska. Geomorphology, 51: 225-242.

Gregory, S.V., Boyer, K.L. and Gurnell, A.M. (Editors), 2003. The Ecology and Management of Wood in World Rivers. American Fisheries Society Symposium 37. American Fisheries Society, Bethesda, Maryland, USA. 
Gurnell, A.M., 2013. Wood in Fluvial Systems. In: John F. Shroder (Editor-in-chief), Wohl, E. (Volume Editor). Treatise on Geomorphology, Vol 9, Fluvial Geomorphology, San Diego: Academic Press, 163188.

Gurnell, A.M., 2014. Plants as river system engineers. Earth Surface Processes and Landforms, 39: 425.

Gurnell, A.M., Corenblit, D., García de Jalón, D., González del Tánago, M., Grabowski, R.C., O'Hare, M.T. and Szewczyk, M., 2016. A conceptual model of vegetation-hydrogeomorphology interactions within river corridors. River Research and Applications, 32(2): 142-163.

Gurnell, A.M. and Petts, G.E., 2002. Island-dominated landscapes of large floodplain rivers, a European perspective. Freshwater Biology, 47: 581-600.

Gurnell, A.M. and Sweet, R. 1998. The distribution of large woody debris accumulations and pools in relation to woodland stream management in a small, low-gradient stream. Earth Surface Processes and Landforms 23, 1101-1121.

Gurnell, A.M., Petts, G.E., Hannah, D.M., Smith, B.P.G., Edwards, P.J., Kollmann, J., Ward, J.V. and Tockner, K., 2001. Riparian vegetation and island formation along the gravel-bed Fiume Tagliamento, Italy. Earth Surface Processes and Landforms, 26(1): 31-62.

Gurnell, A.M., Piégay, H., Swanson, F.J. and Gregory, S.V., 2002. Large wood and fluvial processes. Freshwater Biology, 47(4): 601-619.

Gurnell, A., Tockner, K., Edwards, P.J. and Petts, G.E., 2005. Effects of deposited wood on biocomplexity of river corridors. Frontiers in Ecology and Environment, 3(7): 377-382.

Linstead, C. and Gurnell, A.M. 1999. Large woody debris in British headwater rivers. R\&D Technical Report W181, Environment Agency, Bristol, UK.

Mott, N. (2010) Fish Live in Trees Too! River Rehabilitation and Large Woody Debris. Staffordshire Wildlife Trust, Stafford, UK.

Nakamura, F., Seo, J.I., Akasaka, T. and Swanson, F.J., 2017. Large wood, sediment, and flow regimes: Their interactions and temporal changes caused by human impacts in Japan. Geomorphology, 279: 176-187.

Nanson, G. C. 1980. Point bar and floodplain formation of the meandering Beatton River, northeastern British Columbia, Sedimentology, 27, 3-29.

Nanson, G. C. 1981. New evidence of scroll-bar formation on the Beatton River, Sedimentology, 28(6), 889-891.

Nilsson C, Svedmark M. 2002. Basic principles and ecological consequences of changing water regimes: riparian plant communities. Environmental Management 30(4): 468-480.

Page, K. and Nanson, G., 1982. Concave-bank benches and associated floodplain formation. Earth Surface Processes and Landforms, 7: 529-543.

Palmer, M.A., Bernhardt, E.S., Allan, J.D., Lake, P.S., Alexander, G., Brooks, S., Carr, J., Clayton, S., Dahm, C.N., Follstad Shah, J., Galat, D.L., Loss, S.G., Goodwin, P., Hart, D.D., Hassett, B., Jenkinson, R., Kondolf, G.M., Lave, R., Meyer, J.L., O'Donnell, T.K., Pagano, L. and Sudduth, E., 2005. Standards for ecologically successful river restoration. Journal of Applied Ecology, 42(2): 208-217.

Palmer, M.A., Hondula, K.L. and Koch, B.J., 2014. Ecological Restoration of Streams and Rivers: Shifting Strategies and Shifting Goals. In: D.J. Futuyma (Editor), Annual Review of Ecology, Evolution, and Systematics, Vol 45. Annual Review of Ecology Evolution and Systematics, pp. 247-269. 
Perry, L.G., Reynolds, L.V., Beechie, T.J., Collins, M.J., and Shafroth, P.B. (2015) Incorporating climate change projections into riparian restoration planning and design. Ecohydrology, 8: 863-879.

Pilotto, F., Bertoncin, A., Harvey, G.L., Wharton, G. and Pusch, M.T. (2014), Diversification of stream invertebrate communities by large wood. Freshwater Biology, 59: 2571-2583.

Pitt, M., 2008. The Pitt Review: lessons learned from the 2007 floods. London: Cabinet Office.

Ravazzolo, D., Mao, L., Picco, L., Sitzia, T. and Lenzi, M.A., 2015. Geomorphic effects of wood quantity and characteristics in three Italian gravel-bed rivers. Geomorphology, 246: 79-89.

RRC, 2013. Manual of river restoration techniques. Bedfordshire: The River Restoration Centre. Available at: http://www.therrc.co.uk/manual-river-restoration-techniques [Accessed 28 January 2018].

Sear, D., Wilcock, D., Robinson, M. andFisher, K., 2000. River channel modification in the UK. In The Hydrology of the United Kingdom: a study of change (ed. M. Acreman). Oxford: Routledge.

Sedell, J.R., Bisson, P.A., Swanson, F.J. and Gregory, S.V., 1988. What we know about large trees that fall into streams and rivers. In: C. Maser, R.F. Tarrant, J.M. Trappe and J.F. Franklin (Editors), From the Forest to the Sea: a story of fallen trees. USDA Forest Service General Technical Report PNW229, pp. 47-82.

Thompson, M.S.A., Brooks, S.J., Sayer, C.D., Woodward, G., Axmacher, J.C., Perkins, D.M. and Gray, C. 2017. Large woody debris "rewilding" rapidly restores biodiversity in riverine food webs. Journal of Applied Ecology, 2017, 1-10.

van de Lageweg, W.I., van Dijk, W.M., Baar, A.W., Rutten, J., Kleinhans, M.G. 2014. Bank pull or bar push: What drives scroll-bar formation in meandering rivers? Geology, 42, 319-322.

Wohl, E., 2015. Of wood and rivers: bridging the perception gap. Wiley Interdisciplinary ReviewsWater, 2(3): 167-176.

Zen, S., Gurnell, A.M., Zolezzi, G. and Surian, N. (2017) Exploring the role of trees in the evolution of meander bends: the Tagliamento River, Italy. Water Resources Research, 53,

doi:10.1002/2017WR020561. 